\title{
STUDENTS' SITTING PREFERENCES AT PLAZA IN EDUCATIONAL INSTITUTION
}

\author{
Syam Rachma Marcillia ${ }^{{ }^{*}}$, Diana Kesumasari ${ }^{2}$ \\ ${ }^{1,2}$ Department of Architecture and Planning, Universitas Gadjah Mada, Jl. Grafika No. 2, \\ Bulaksumur Yogyakarta 55281, Indonesia \\ *Corresponding author; Email: syam.r.m@ugm.ac.id
}

\begin{abstract}
The purpose of this research is to understand the relationship between sitting preferences and student activities by taking the case of public plaza at the Central Office of the Faculty of Engineering (KPFT) Universitas Gadjah Mada (UGM) in Yogyakarta. KPFT UGM as research object is divided into five zones, namely Zone A (west), Zone B and C (south), and Zone D and $\mathrm{E}$ (north). Field observation was done within one month period during working days (weekday) and weekends with observation time: in the morning (08.00-10.00), noon (12-14.00), and afternoon (16.00-18.00). In each of the observation zone, a place-centered mapping was investigated continuously. Informal interview and the questionnaire from 200 students as respondents also undertaken in this research. The results of this study showed that the students' sitting preferences in the KPFT UGM influenced by the activities that they did. Some of the factors that affect the students' sitting preferences are: 1) type of activities, 2) the number of people engage in the activity, 3) privacy needs, 4) the needs of the facilities, and 5) the distance between sitting zone in the KPFT UGM and the students' major buildings.
\end{abstract}

Keywords: Sitting preferences; student activity; plaza in educational institution.

\section{INTRODUCTION}

A communal space in an educational institution does not only has a function as gathering space or as a place of social interaction for students, but with a thoughtful planning it can be used as facilities for students to perform various secondary activities within the space. These secondary activities are performing tasks, discussions, gathering, browsing information, exhibition and others. These kind of communal space also the function of public Plaza at KPFT UGM.

Plaza KPFT UGM is one of many informal learning spaces that provided by the campus for students to support their academic activities and social interactions. Jamieson (2009) in McDaniel (2014) define informal learning as learning activities conducted by the individuals and groups that occurs outside the classroom. This activity is free from the lecturers' instructions and in general can be understood as supporting learning activities that occur outside the formal learning settings in the classroom. In the classroom, students usually spend hours and are expected to behave formally. Therefore when the students are finished with their formal classes or have extra time in between the formal classes' hours, they will search for the most interesting space for them. Space that is comfortable and can be adjusted with the students' needs tend to be chosen by the students to spend their time. The types of activities that are common in the informal space include reading, working tasks and projects individually and in groups. Informal learning space that is located outside the classroom usually occurs in the library, cafes, or another location that allows students to gather (Lomas, 2006).

Basically student learning activities can be divided into two types (Faizati, 2013), e.g. a), active learning activities that require movements or interactions with one another, for example the exhibitions, experiments and discussions, and $b$ ), passive learning activities that don't require a lot of movements or interactions with one another, for example searching for literature, reading the book, drawing and writing. McDaniel (2014) said that the majority of students nowadays prefer active learning, participatory and experiential learning. More students choose to participate actively in seeking knowledge than receiving knowledge passively. To accommodate this alteration, environment can be designed in such a way to become a flexible environment, comfortable and interesting for the students (Siddall, 2006) in McDaniel (2014). Flexibility has become one space characteristic that capable to accommodate the informal learning space because it allows students to adapt the physical environment for their individual preferences. Room with comfortable furniture, table variety for different ergonomic, access for food and drinks and casual atmosphere (contrasted with formal space as class room) are more interesting for informal 
learning space. Research results from Tibbetts (2008) in McDaniel (2014) said that students spend more time in a room that the layout can be adjusted according to their needs.

KPFT UGM as plaza campus provided due to the mutual relationship between the two parties: the institution (university) and the students. The needs of the institution is to provide the appropriate learning space that align with students' preferences so that the provision of the learning can be optimum, while the needs of the students is the existence of learning space that facilitates learning activities and social interactions. Riddle \& Souter (2012) said that a lot of the study area designs on campus did not heed with the students' perspectives and created a learning space that is less suitable for active learning, peer learning and learning supported by technologies as one of the modern learning environment characteristics is inseparable from the role of technology. There is a change of the learning trend: from using conventional books in the library to learn with internet media on areas outside the classroom. Nowadays many students use laptops to support their activities in campus, for learning, performing tasks or simply for entertaining, such as streaming music and videos.

Various students' activities should accommodated with an optimum setting space that able to support their activities. The space layout, especially the seating pattern is expected to be able to support student activities. Laurens (2005) says that the layout of the specific space can affect social interaction in a positive or negative way. There are some researches that focus on the role of personal space in the environment and some of them are related with furniture layout, especially in public spaces such as schools, office buildings and the airport. Basically there are two kinds of spaces that can be influential in social interactions: 1) sociopetal space, defines as the space order that is capable of facilitating the social interactions, and 2), sociofugal space, defines as the space order that can reduce the social interactions. In addition to the styling furniture, formation of any spaces will have a very important role in the success of forming sociopetal space. The example of sociopetal space is the dining table that allows each family member sat opposite one another, whereas for sociofugal space is often found on the airport or railway station waiting room where visitors can sit with their backs to each other without the need of social interaction.

Haghighi (2012) said that the configuration from the sitting arrangements can have a positive or negative impact on the students' performances. Sitting arrangements also affect students' social interactions.
Therefore, to create a learning environment through the seating layout can help the achievement of the learning process itself. Some learning style researches are taking in classroom and library setting. Stenzor (1950) and Gump (1987) in Haghighi (2012) said the students that sit around the table can build a face-toface contact more easily than those who sit in the form of the line (row) seats. Horse shoe shape can support the interaction between lecturers and students and also can increase a sense of the community ownership itself because instead of facing lecturers, students face each one another (Hurt et al. 1978) in Haghighi (2012). Atherton (2005) in Haghighi (2012) said that the active learning in the classroom can be better created through a circle or a cluster seating form.

Condon (1966) in Young (2003) wrote about the learning style and the students' learning spaces desire. $\mathrm{He}$ found that there are some space preferences desired by students for learning, such as access to take the book, location in the small room for the group learning and location in a room that is exclusively used to learn. Sommer (1968) in Young (2003) make the questionnaire for students located in the library, classrooms, dormitory rooms and other spaces in campus environment to understand why students learn on these spaces. They selected library because of the atmosphere that makes people want to learn, although it's less private when compared with the dormitory rooms.

On the other article, Sommer (1966) in Young (2003) noted that although the library is preferred as the study area, other students prefer to learn in public area because of the independence, space openness, and different atmosphere to learn which is termed by Sommer as social increment; defines as to see other people study, increase the individual desire to study too. How students make a space to study for himself when he was in the library or other spaces are referring to Sommer's theory about personal space. Sometimes these were done through adjustments and changes of tables and chairs arrangements. Some changes are made to accommodate a group of two or more students who want to study together. Eastman and Harper (1971) in Young (2003) said that there is a clear conflict that occurs between students who want to study in individuals and students who want to study in groups. This situation can happen because there are differences in privacy needs.

Rapoport (1977) in Halim (2005) explain privacy as the ability to control the interaction, to have the choice and to get the desired interaction. Therefore, privacy should not only be seen as someone's physically withdrawal from other people (Schwarts, 
1968) in Halim (2005). Westin (1970) in Altman (1975) distinguish four types of privacy: 1) solitude, defines as the situation that free from others observation, 2) intimacy, defines as the situation that surround with other people but free from the outside world, 3) anonymity, defines as the situation that is not recognized even in the crowd, and 4) reserve, defines as the situation where someone makes a psychological restrictions to control unwanted interruptions. Keppell \& Riddle (2011) in the Riddle \& Souter (2012) says that in busy hours, students have difficulties to access the computers and wi-fi in library. Therefore, some students want a place to study in private and comfortable in campus with facilities to sockets for laptop and longer open hours.

Keskin (2013) said that the use of natural lighting is essential for the space where people spend a lot of time to perform tasks related to the visual work such as reading and writing. This is due to the fact that such activities require a certain natural lighting quality. Fishman \& Walitt (1972) in Keskin (2013) that study the relationship between the architectural room factor and seating preference pattern for library users shows that there is a tendency whereas some individuals occupying the same seats in certain period of time and there is a seating preference where they distanced themselves from the existence of other people for their privacy needs.

Painter et. al. (2013) said the open space with natural lighting and freedom to behave are capable to create a more conducive informal learning space than in a controlled gathering areas such as library where the tranquility is expected. In this research, plaza KPFT UGM was chosen as the location of the case study because the space was considered more casual than the library. It is also a public space that the students use for their activities including study, doing task, projects, etc. Plaza KPFT UGM is a semioutdoor space that rely on natural lighting during the daytime. Its location in the center of the Engineering Faculty Universitas Gadjah Mada also become consideration because it can be accessed easily by Engineering students from different majors around in the area, even by the students outside of the Engineering faculty.

In the plaza KPFT UGM there are areas that occupied with a lot of students while in other areas aren't. These condition lead to a hypothesis that there is students' preferences in selecting the sitting areas in the plaza that relates to their activities. The purpose of this research is to understand the students' sitting preferences that relate to their activities in KPFT UGM as a plaza in educational institution. It is expected that from this research the university can provide a better informal learning space to support and improve the learning quality of students.

\section{RESEARCH METHODOLOGY}

The research location is plaza KPFT UGM which can be categorized as a semi-outdoor plaza campus. The space layout and activities in this research based on the field observation result during August - September 2016. The field observation was done within one month period during working days (weekday) and weekends. The time frame observation was divided into morning (08.00-10.00), noon (12-14.00), and afternoon (16.00-18.00). Some functions that accommodated in the KPFT UGM include: 1) as studying facilities equipped with high speed Wi$\mathrm{Fi}, 2$ ) as an exhibition room for student activities, 3) as a space for student club discussion, 4) as a place for chatting and gathering, etc. The type of facilities that are provided in the KPFT UGM include: 1) the builtin wooden tables that are attached to the columns, 2) wooden tables and chairs, 3) circular seats, 4) bulletin boards, 5) ATM machines, 6) a vendor machine, and 7) a "Teknik" Mart. To facilitate observation, plaza KPFT UGM is divided into five zones.

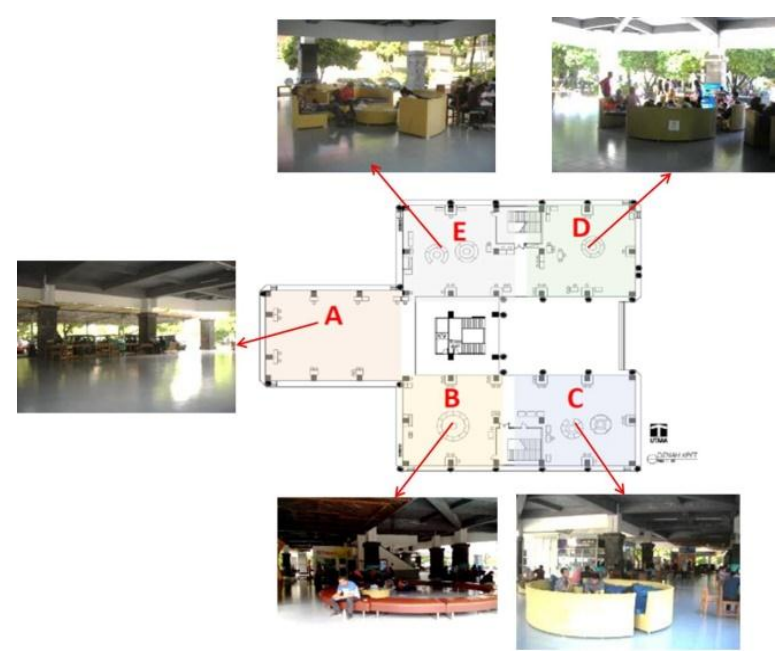

Fig. 1. The Observation Zone (Source: Observations, 2016).

The respondents in this research are the plaza KPFT UGM users which mostly from Universitas Gadjah Mada students, either from Engineering faculty students or from other faculties in Universitas Gadjah Mada. This research take 200 respondents (42 respondents in zone A, 41 respondents in zone $\mathrm{B}, 36$ respondents in zone $\mathrm{C}, 36$ respondents in zone $\mathrm{D}$, and 45 respondents in zone E). Respondents were asked to fill the questionnaire that has been provided in order to understand their sitting preferences in the plaza KPFT UGM. 
The instrument used as documentation tools include cameras digital, and the notebook. The type and data sources include: 1) primary data obtained from the interview, field observation, and placecentered mapping, 2) secondary data obtained from the study literature. The data obtained as empirical data consists of the sitting behaviors and specific behaviors documentation. The data collection technique is done through observation, place-centered mapping, physical setting documentation and questionnaire. The physical setting data obtained directly from the field observation include images and floor plan of the plaza KPFT UGM. The place-centered mapping was taken to find the area tendency mostly used by students to sit. The questionnaire was used to know areas where students' preference to sit as their favorite place and last choice when plaza is full, reasons for the students to choose specific seats, and activities that they are doing. Informal interview was used to support the data from the questionnaire results. The data were processed and analyzed so that the conclusions can be made regarding the relationship between the students' sitting preferences and activities that occur on the KPFT UGM.

\section{RESULTS AND DISCUSSION}

From 200 respondents in five observation zones, the characteristics of respondents was able to be obtained as shown in Table 1.

From the questionnaire results, we can learn that the students come to the plaza in a month was almost every day $(52 \%)$, with the day they normally came was in the weekday $(47.0 \%)$, and the time they normally came was depending on their needs or flexible $(50.5 \%)$. The reasons students came to KPFT UGM to perform their activity were because: 1) adequate facilities (61.0\%), and 2) close to the respondents' major building $(25.0 \%)$. The intended facilities including the availability of the sockets, wi-fi router, and the number of desks and chairs that are able to accommodate the students' way of learning needs. In addition, proximity factors between the KPFT UGM and students' major building was also became one factor of the seating preference. For example the students who came and sat in zone A have major in Physics, Industrial, and Civil. When these majors were being compared to the KPFT UGM area, it is obvious that indirectly proximity

Table 1. The Characteristic of Respondents

\begin{tabular}{|c|c|c|c|c|c|}
\hline & A Zone & B Zone & CZone & D Zone & E Zone \\
\hline Total of respondents & $\begin{array}{c}42 \text { persons } \\
(27 \text { male, } 15 \text { female) }\end{array}$ & $\begin{array}{c}41 \text { persons } \\
(23 \text { male, } 18 \text { female })\end{array}$ & $\begin{array}{l}36 \text { persons } \\
\text { (21 male, } 15 \\
\text { female) }\end{array}$ & $\begin{array}{c}36 \text { persons } \\
\text { (20 male, } 16 \text { female) }\end{array}$ & $\begin{array}{c}45 \text { persons } \\
(22 \text { male, female } 23)\end{array}$ \\
\hline Age & 19-20 years old & $19-20$ years old & 19-20 years old & $19-20$ years old & 18-19 years old \\
\hline Education level & $\mathrm{S} 1$ & $\mathrm{~S} 1$ & S1 & $\mathrm{S} 1$ & $\mathrm{~S} 1$ \\
\hline Semester & 3 & 3 & 3 & 3 & 3 \\
\hline Faculty & Engineering UGM & Engineering UGM & Engineering UGM & Engineering UGM & Engineering UGM \\
\hline Dominant majors & $\begin{array}{l}\text { 1. Physics } \\
\text { 2. Industry } \\
\text { 3. Civil }\end{array}$ & $\begin{array}{l}\text { 1. Geology } \\
\text { 2. Civil } \\
\text { 3. Industry }\end{array}$ & $\begin{array}{l}\text { 1. Civil } \\
\text { 2. Industry } \\
\text { 3. Physics }\end{array}$ & $\begin{array}{l}\text { 1. Physics } \\
\text { 2. Civils } \\
\text { 3. Chemicals }\end{array}$ & $\begin{array}{l}\text { 1. Chemicals } \\
\text { 2. Civil } \\
\text { 3. Industry }\end{array}$ \\
\hline Total come in a month & Almost every day & Almost every day & Almost every day & Almost every day & Almost every day \\
\hline The day normally came & Flexible & Weekday & Flexible & Weekday & Weekday \\
\hline The time normally came & Flexible & Flexible & Flexible & Flexible & Flexible \\
\hline The reasons to come to & 1. Adequate facilities 1 & 1. Adequate facilities & 1. Adequate facilities & 1. Adequate facilities & 1. Adequate facilities \\
\hline KPFT UGM & $\begin{array}{l}\text { 2. Close to the } \\
\text { respondents' major } \\
\text { building }\end{array}$ & $\begin{array}{l}\text { 2. Close to the } \\
\text { respondents' } \\
\text { major building }\end{array}$ & $\begin{array}{l}\text { 2. Close to the } \\
\text { respondents' } \\
\text { major building }\end{array}$ & $\begin{array}{l}\text { 2. Close to the } \\
\text { respondents' major } \\
\text { building }\end{array}$ & $\begin{array}{l}\text { 2. Close to the } \\
\text { respondents' major } \\
\text { building }\end{array}$ \\
\hline The purpose to come in & 1. Group discussion & 1. Study with $1-2$ & 1. Group discussion & 1. Individual study & 1. Individual study \\
\hline KPFT UGM at this time & $\begin{array}{l}\text { 2. Individual study } \\
\text { 3. Study with } 1-2 \\
\text { friends }\end{array}$ & 2. Group discussion & $\begin{array}{l}\text { 2. Study with } 1-2 \\
\text { friends } \\
\text { 3. Browsing }\end{array}$ & $\begin{array}{l}\text { 2. Browsing } \\
\text { 3. Study with 1-2 } \\
\text { friends }\end{array}$ & $\begin{array}{l}\text { 2. Group discussion } \\
\text { 3. Browsing }\end{array}$ \\
\hline $\begin{array}{l}\text { The reason for seats' } \\
\text { selecting at this time }\end{array}$ & $\begin{array}{l}\text { 1. Near with the } \\
\text { sockets } \\
\text { 2. Near with the wi-fi } 2 \\
\text { router } \\
\text { 3. Only this seat that } \\
\text { is empty }\end{array}$ & $\begin{array}{l}\text { 1. Near with the } \\
\text { sockets } \\
\text { 2. Only this seat that } \\
\text { is empty }\end{array}$ & $\begin{array}{l}\text { 1. Near with the } \\
\text { sockets } \\
\text { 2. Only this seat that } \\
\text { is empty } \\
\text { 3. Near with the wi- } \\
\text { fi router }\end{array}$ & $\begin{array}{l}\text { 1. Near with the } \\
\text { sockets } \\
\text { 2. Comfortable seats } \\
\text { 3. Near with the wi-fi } \\
\text { router }\end{array}$ & $\begin{array}{l}\text { 1. Near with the } \\
\text { sockets } \\
\text { 2. Only this seat that } \\
\text { is empty }\end{array}$ \\
\hline $\begin{array}{l}\text { How much time the } \\
\text { respondents was able to } \\
\text { sit in KPFT UGM }\end{array}$ & $1-3$ hours & More than 3 hours & More than 3 hours & $1-3$ hours & More than 3 hours \\
\hline How to get the seats & Flexible & Flexible & Flexible & Flexible & Flexible \\
\hline
\end{tabular}


factors between students' major building was relate to the preferences in selecting areas where they sat. Students tend to occupy areas that near with their major building.

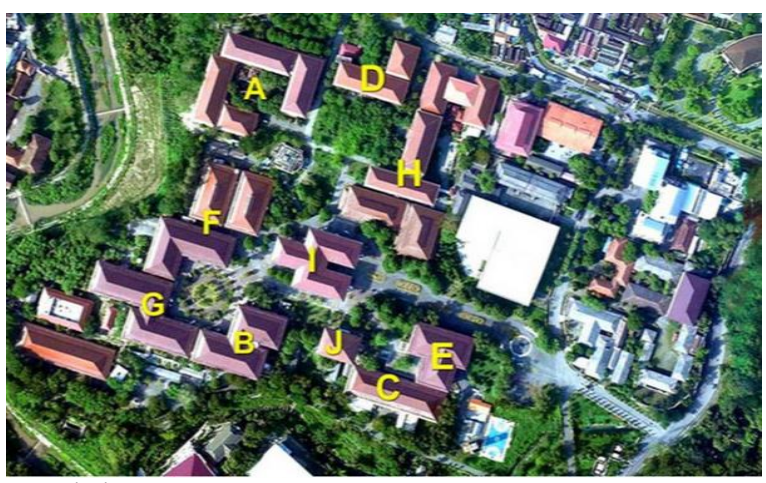

Description:

A: Architecture

B : Electrical Engineering and Information Technology

C: Physics

D: Geodesy

E: Geology

F : Chemical

$\mathrm{G}$ : Mechanical Engineering and Industry

$\mathrm{H}$ : Civil

I : Central Office of the Faculty of Engineering (KPFT UGM)

$\mathrm{J}$ : Library

Fig. 2. The Engineering Faculty Universitas Gadjah Mada Map (Source: http://ft.ugm.ac.id/tentang-ft/peta-ft/, accesed October, $\left.7^{\text {th }}, 2016\right)$.

Seating codes were given on each of the seats on the KPFT UGM to facilitate observation. The seating codes then applied on the questionnaire to understand the students' sitting preference that relate to their activities.

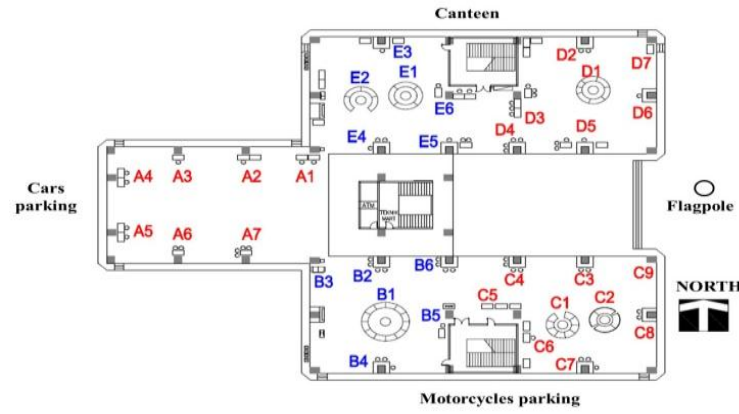

Fig. 3. Seating Codes in KPFT UGM (Source: Observations, 2016).

The type of the seats in each areas in plaza KPFT UGM can be categorized into 4 types, namely:

a) Wooden desks and chairs (figure 4 left).

Mostly found in zone A, this seats are flexible. It means that when they needed by the students, they can be moved into an area that the students choose. This condition usually occurs when the students come in groups but the available seatings could not accommodate their needs so that they have to do an adjustment. b) Wooden desks that attached to the column and wooden chairs (figure 4 right).

This seats mostly found at the edge of plaza KPFT UGM, except in zone A. The wooden desks are fixed type, which means they can not be moved, while wooden chairs are flexible or can be moved according to the students' needs. When the students come in groups, they will move the wooden chairs to the wooden desks that attached to the column so that discussion activity can happen. The desks are also be equipped with 4 sockets to accommodate the electricity needs because most students are working by using laptops.

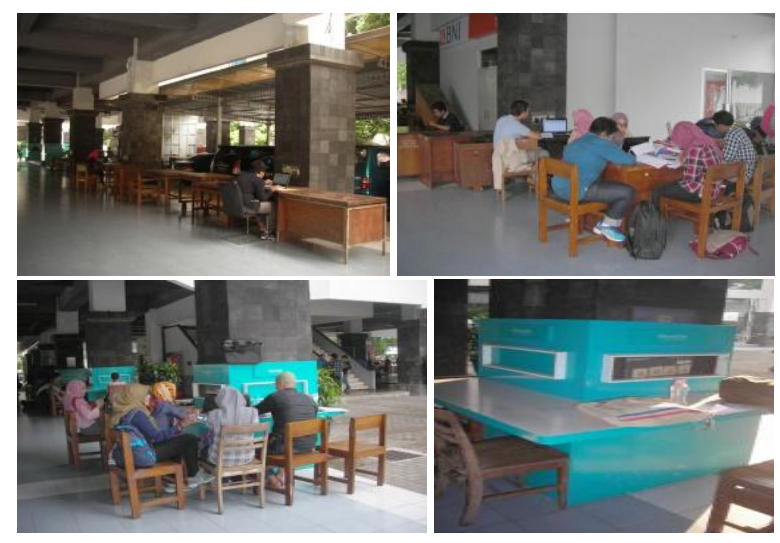

Fig. 4. Wooden Desks and Chairs (Left), Wooden Desks and Wooden Chairs That Attached to The Column (Right) (Source: Observations, 2016).

c) Circular seats without backrest (figure 5 left).

This type of seats found almost on whole areas, except zone A. These seats are fixed type, because their legs are chained so that the students could not move the seat parts. The only thing that can be moved is the inner round table.

d) Circular seats with backrest (figure 5 right)

This seats can be found in zone $\mathrm{C}$ and $\mathrm{E}$. Different from the circular seats without backrest, these seats are flexible because their legs are not chained so they can easily be moved.

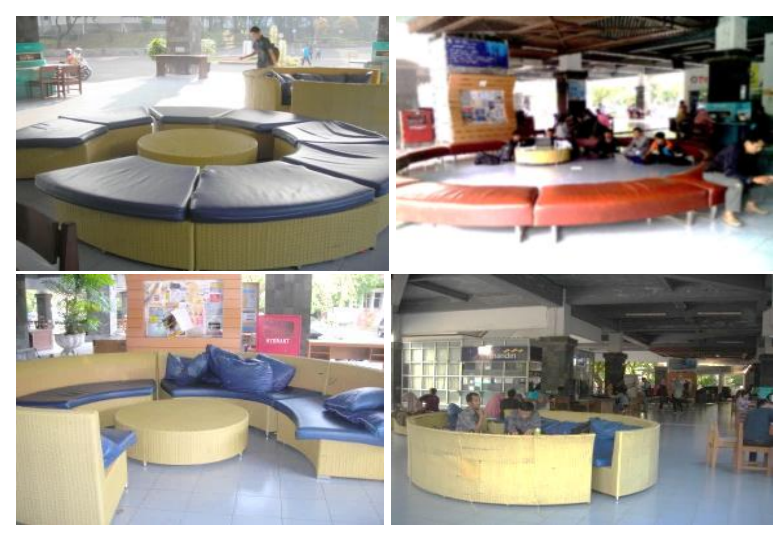

Fig. 5. Circular Seats Without Backrest (Left), Circular Seats With Backrest (Right) (Source: Observations, 2016). 
Based on the results of the questionnaire, seating arrangement can be categorized base on students' preference associated with the activities that they do at that time.

Favorite seats when respondents are alone and when with 1-2 friends on each zone are both wooden desks - chairs and wooden desks that attached to the column - wooden chairs. The same result is also found in the category of first choice seats when respondents are performing internet browsing and when studying alone. For these activities, most students choose the seats that is located at the edge of the plaza. There is no student who choose the circular seats as their favorite place when they are alone in the plaza KPFT UGM. Based on the results of the questionnaire, some reasons why students choose the wooden desks and chairs as their favorite seat when come alone or with 1-2 friends on each zone are:

a) The availability of sockets, and wi-fi speed $(31.0 \%)$

b) The privacy needs and wi-fi speed (22\%)

c) The needs of the lighting, and wi-fi speed (13.5\%)

These founding is in line with the privacy needs for students' sitting preferences. Most of the students that come to the plaza KPFT UGM are studying alone, therefore they deliberately withdraw themselves from the noises and crowds so that they can do their tasks effectively and not be disturbed. Based on the interview results, some students who are per-

Table 2. The Type of The Seats By Category

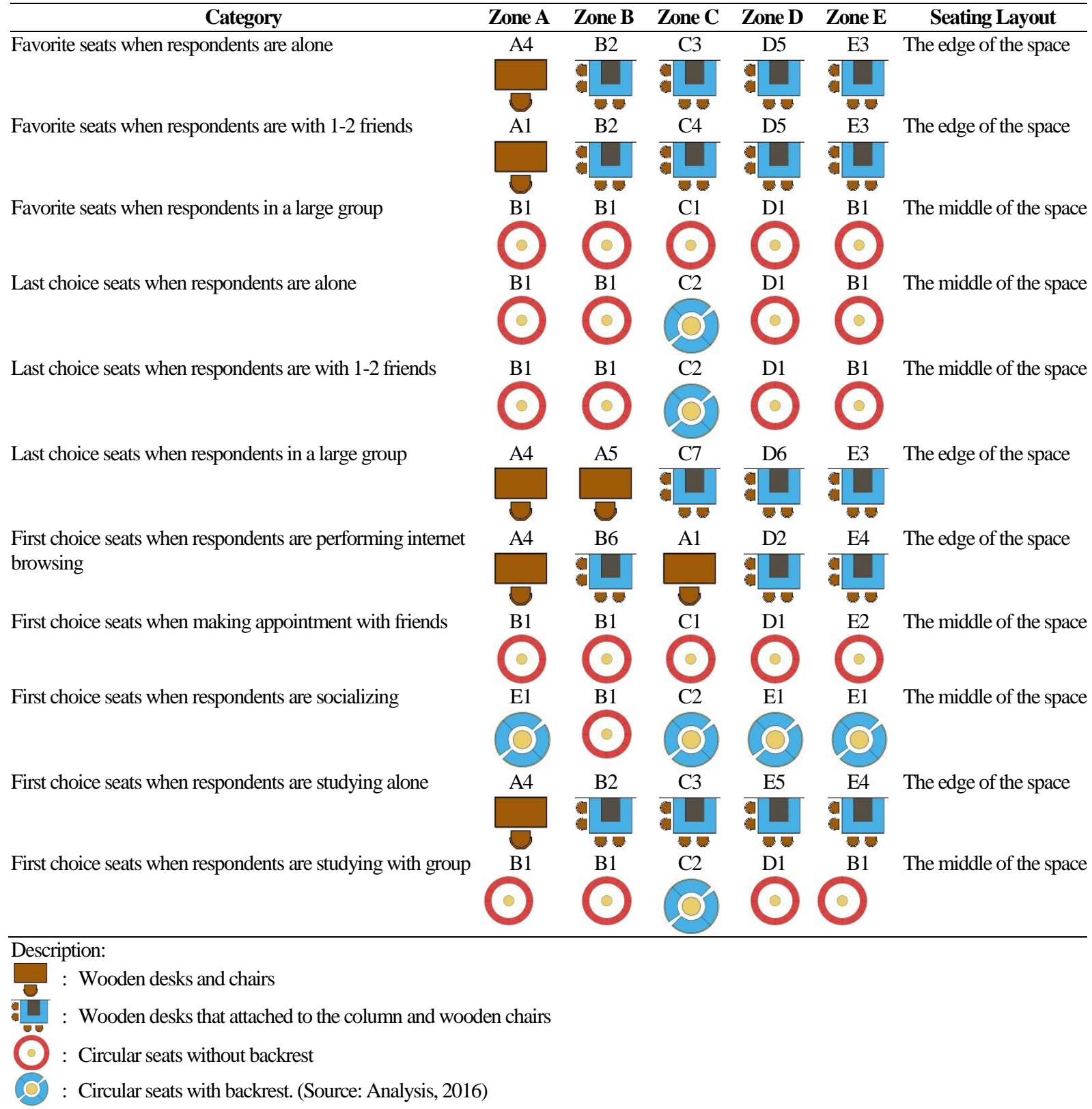


forming internet browsing in zone A said that they deliberately choose a place to sit as far as possible from the crowds because they did not like when there are other people who pass by and see what they do deliberately or accidentally. Westin (1970) in Altman (1975) mentions this condition with the term "solitude", which is a condition in which a person deliberately withdraw from the crowd with the purpose of free from observation of others.

In addition, facilities such as the availability of sockets, wi-fi and the space lighting are also needed to support students' tasks performance that usually takes more than 3 hours $(41.0 \%)$. The wooden table and chairs classified as more ergonomics for working with laptop (when compared to the circular seats), so the students are capable to work for more than 3 hours. In contrary, last choice seats when respondents are alone and when with 1-2 friends are the both circular seats with backrest and without backrest. This is due to the fact that circular seats usually used as a discussion space by some students, so they are uncomfortable when being used by students who came alone. Based on the results of the interview, some students feel disturbed, crowded, and cannot concentrate when they are sitting on the circular seats. This founding correlated to the theory of sociopetal - sociofugal space whereas according to Laurens (2005), the layout of the specific space can affect social interaction positively or negatively.

On the other hand, for group's task almost all students preferred to be working on the circular seats that are located in the middle of the plaza KPFT UGM, while the wooden desks and chairs is the last preference when they came as a group to the plaza. The same preference is seen in the category of sitting preference when making appointment with friends, chatting, and working group task. Based on the results of the questionnaire, many students prefer to sit on the circular seats while working group work with consideration such as:

a) More interactive discussions whilst sitting on the floor (with moving the inner round table to the edge) $(34.0 \%)$

b) Sitting place more suitable for discussion, but the students' could not work for a long time because they not ergonomics (28.0\%).

Based on the results of the interview, many students deliberately choose to sit on the floor in the circular seat without backrest, especially in B1. This is because they feel more comfortable in discussion on the floor (lesehan) rather than using wooden chairs. Adjustment to the seat was made by moving the inner round table to accommodate the needs of the table for laptop (figure 6).

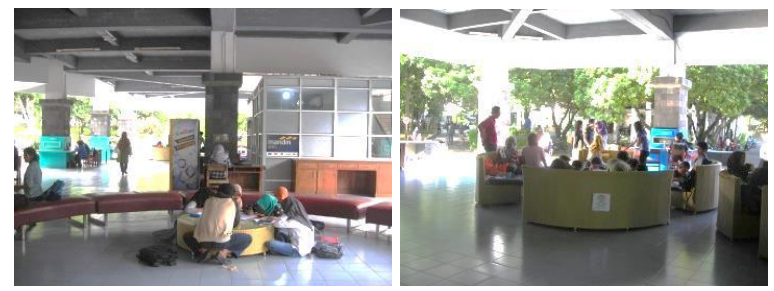

Fig. 6. The Use of Circular Seat for Performing Group Tasks (Source: Observations, 2016).

Based on the results of the questionnaire, some of the reasons students choose to sit on the circular seats without backrest for making appointment with friends are:

a) Strategic location, circular seats in zone B and C are visible from the motorcycles parking (49\%)

b) Strategic location, circular seats in zone D and $\mathrm{E}$ are visible from the canteen and mosque (16.5\%)

c) Strategic location, circular seats in zone C and D are visible from the access to the Engineering Faculty (16\%)

While some of the reasons students choose to sit on the circular seats with backrest for chatting with friends because:

a) Comfortable seats, because they have backrest $(51.0 \%)$

b) Comfortable seats (49\%)

Based on the place-centered mapping results, zone $\mathrm{B}, \mathrm{C}, \mathrm{D}$ and $\mathrm{E}$ are zones that firstly occupied by the student while zone A is the last zone to be fully occupied by students. Therefore, when students need privacy to do the task alone, usually he/she will go to zone A. From the founding relate to privacy, plaza KPFT UGM can be categorized into zoning as shown in figure 7.

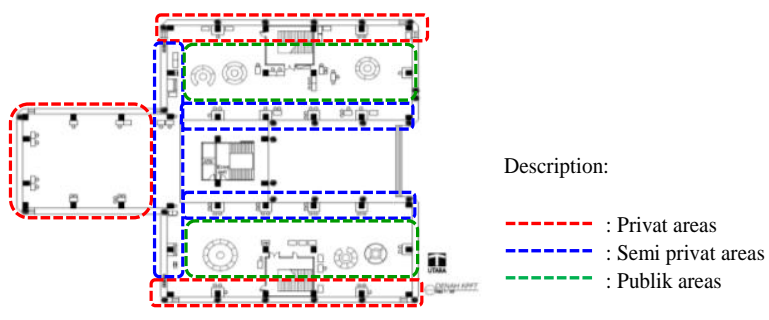

Fig. 7. KPFT UGM Zonification (Source: Observations, 2016).

Based on the results of the questionnaire and place-centered mapping, it can be said that zone A and the edges area of plaza KPFT UGM can be referred to as private areas. This is in accordance with the students' preference that come to the plaza by themselves where they mostly select the seats which is far from the noise and even prefer to sit at the 
corner or edges of the room to protect their privacy. The inside edges of the plaza KPFT UGM border can be categorized as semi private areas. This is in accordance with the students with 1-2 friends' preference who do not reject the crowds because their privacy need is not as high as the students who come alone. Whereas the middle areas where the circular seats were placed can be categorized as public areas. This is due to that most students who sit in this areas do not reject the crowds, even if the noises mix with their activities. Therefore, these areas are often used by students who come in groups.

From the explanation above, we can learn that the factors that affect the students' sitting preference in the plaza KPFT UGM are as follows:

1) The type of activities

Students who want to do the task alone or simply to perform internet browsing choose to sit on wooden desks and chairs that are located on the edge of the space, while the students who simply chat, have appointment with friends or working in a group prefer to sit on circular seats that located in the middle of the space.

2) The number of people engage in the activity (alone, with 1-2 friends, or groups)

Students who come alone or with 1-2 friends prefer to sit on the wooden desks and chairs located on the edge of the room, while the students who come in groups prefer to sit on the circular seat which is located in the middle of the space because the area is considered large enough to accommodate their group activities.

3) Privacy needs

Students who come alone mostly requires a high level of privacy and feel disturbed when they are in a crowded space. Students who come alone on average chose to sit as far as possible from the crowd, even if they have to sit at the corner or edges of the room where he feels his privacy protected so that he is able to do the task. Students who come with 1-2 friends on average chose to sit on wooden desks and chairs located on the edge of space. But they do not reject the crowds because their privacy need is not as high as the students who come alone. While the students who came in groups on average chose to sit on the circular seats because for them the most important factor is the space able to accommodate the number of those who come even though they have to perform tasks on the floor and in the middle of the crowd (mixes with the noise that is not part of their discussion).

4) The needs of the facilities

The needs of facilities such as sockets and Wi-Fi router also influential on students' preferences. Students who come alone on average chose to sit on wooden chairs that tend to be close to $\mathrm{Wi}-\mathrm{Fi}$ router and able to protect their privacy. Students who come with 1-2 friends on average chose to sit on wooden desks and chairs that are able to accommodate the sockets needs and tend to be close to the Wi-Fi router. While the students who come in groups mostly select the seats that can accommodate the number of them, and able to accommodate the sockets needs and tend to be close to the Wi-Fi router.

5) The distance between sitting zone in the KPFT UGM and the students' major buildings

Mostly students who come to the KPFT UGM choose to sit on zone that considerably near with their major building. If the sitting area that close to their major building is still available, then they will choose to sit on it.

\section{CONCLUSION}

The results of this study showed that the students' sitting preferences on plaza KPFT UGM influenced by some factors: 1) type of activities, 2) number of people engage in the activity (alone, with 1-2 friends, or group), 3) privacy needs, 4) the needs of the facilities, and 5) the distance between sitting zone in the KPFT UGM and the students' major buildings. To facilitate the differences of privacy needs between students that work alone and in group, there is a need for zoning differentiation even in an open public space between the social learning and individual learning space.

\section{REFERENCES}

Altman, I. (1975). The Environment and Social Behavior: Privacy, Personal Space, Territory and Crowding, Brooks - Cole Publishing Company, Monterey, California.

Faizati, A. (2013). Student Square di Yogyakarta Sebagai Pusat Aktivitas Belajar Mandiri Pelajar dengan Konsep Playful, Pra Tugas Akhir S1 Arsitektur.

Haghighi, M. M., Jusan, M. M. (2012). Exploring Students Behavior on Seating Arrangements in Learning Environment: A Review, ProcediaSocial and Behavioral Sciences, 36, pp. 287294.

Halim, D. (2005). Psikologi Arsitektur (Pengantar Kajian Lintas Disiplin), Grasindo, Jakarta.

http://ft.ugm.ac.id/tentang-ft/peta-ft/, accesed October, $7^{\text {th }}, 2016$

Keskin, Z., Chen, Y., Fotios, S. (2015). Daylight and Seating Preference In Open-Plan Library Spaces, International Journal of Sustainable Lighting, 1, pp.12-20. 
Laurens, J. M. (2005). Arsitektur Perilaku Manusia, Grasindo, Jakarta.

Lomas, C., Oblinger, D. G. (2006). Student Practices and Their Impact on Learning Spaces, in Learning Spaces Handbook (ed. Oblinger Diana G.), an Educause e-book.

McDaniel, S. (2014). Every Space is a Learning Space: Encouring Informal Learning and Collaboration in Higher Education Envirnoments, BWBR, April 2014, pp. 1-8.

Painter, S. et. al. (2013). Research on Learning Space Design: Present State, Future Directions, Report from the Recipients of the 2012 Perry Chapman Prize, Society for College and University Planning, pp.1-40.
Puspita, A. A. et.al. (2013). Kajian terhadap Sarana Duduk Publik Kampus dengan Pendekatan Perilaku dan Aktivitas Warga Kampus (Studi Kasus pada Kampus Institut Teknologi Bandung Ganesha), Jurnal Vis. Art \& Des, 5(1), pp.1-19.

Riddle, M. D. \& Souter Key (2012). Designing Informal Learning Spaces Using Student Perspectives, Journal of Learning Spaces, 1(2).

Young, V. E. (2003). Can We Encourage Learning by Shaping Environment? Patterns of Seating Behavior in Undergraduates, ACRL Eleventh National Conference, April 10.13, 2003, Charlotte, North Carolina. 